seed trade by forming a link between the genetical laboratory and the industry. The Institute is marketing this autumn a new oat, Resistance, which has yielded 32 per cent more than Grey Winter in the Institute's 1931-2 and 1932-3 trials; but this new variety requires clean, rich soil, and early autumn or February sowing in situations which are not too exposed, if its high yielding capacity is to be fully exercised. Sugar beet is another crop on which the Institute has done valuable work. The average yield for Britain is about 8 tons per acre. Many farmers, however, obtain 12-15 tons per acre. From this, it is apparent that the average yield can be, and will be, considerably increased if farmers grow the right strain.

\section{Beit Fellowships for Scientific Research}

Tне following Beit Fellowships for Scientific Research at the Imperial College of Science and Techno. logy, during the Academic Year 1934-35, have been awarded: New Fellowships for one year, renewable for a second year, to Mr. H. I. Stonehill, of East London College, for research into the applicability of the modern theories of strong electrolytes due to Debye, La Mer, Bjerrum, Davies, etc., the experimental work taking the form of measurement of the E.M.F. of certain cells, under Prof. J. C. Philip; Mr. J. R. Tillman, of the Imperial College, for research on electron diffraction, both from the point of view of studying crystal forms and the mechanism of diffraction, under Prof. G. P. Thomson; Mr. J. Bell, of the Imperial College, 1927-34, for a spectrographic investigation of hydrocarbon combustion, under Prof. W. A. Bone. Extensions of fellowships already satisfactorily held for one year have been awarded to Dr. K. Bailey, for research on seed mucocellulose and its relation to the chemistry and hydration of the plant cell wall; Mr. M. Blackman, for research in mathematics on the several different properties of crystal lattices with particular reference to the specific heat; and Mr. S. F. Boys, for research in chemistry and particularly a review of the theoretical work on optical rotatory power.

\section{Beit Memorial Fellowships for Medical Research}

IN announcing the awards made this year of Beit Memorial Fellowships for Medical Research, the trustees state that they were influenced by a special desire to promote research in relation to mental disease. The following elections were made, the subject and place of the proposed investigation being indicated after the name: Fourth Year Fellowships (£500 per annum): Mr. R. Hill, to continue his research on the properties of hæmoglobin and cytochrome (Dunn Institute of Biochemistry and Molteno Institute, Cambridge) ; Dr. L. H. Stickland, to continue work on the metabolism of the strictly anærobic bacteria of the genus Clostridium (Dunn Institute of Biochemistry, University of Cambridge). Junior Fellowships ( $£ 400$ per annum): Dr. S. Zuckerman, experimental study in animals of the neurovascular control of reproductive functions (Department of Human Anatomy, University of Oxford); Mr. H. W.
Fullerton, etiology and treatment of hypochromic anæmia of women of the poor classes (Department of Medicine, University of Aberdeen, and Rowatt Research Institute, Aberdeen); Mr. E. M. Lourie, chemotherapy in protozoal disease (Liverpool School of Tropical Medicine); Mr. J. S. Mitchell, effects of radiation on thin protein films (Laboratory of Colloid Sciences, University of Cambridge); Dr. D. E. Green, effect of hormones and vitamins upon metabolism of individual organs (Institute of Biochemistry, University of Cambridge); Dr. G. A. Grant, metabolism of galactose and the physiological synthesis of lactose by the active mammary gland (Lister Institute of Preventive Medicine, London); Mr. S. L. Cowan, to continue study of the chemical exchanges occurring in crustacean nerve, as a result of stimulation and oxygen want; to study the blood flow through the kidney during diuresis (Pharmacology Laboratories, University of Cambridge); Dr. M. Jowett, metabolism of the central nervous system with reference to the effects of narcotic and basic amines in cases of mental disorder (Bio. chemical Laboratory, Cardiff City Mental Hospital).

\section{Thunderstorms and Lightning}

Prof. B. F. J. Schonland, of the University of Cape Town, has recently given an interesting account of recent advances in our knowledge of thunderstorms (Science Service of June 19). The first noticeable point is that the quantity of electricity stored up in the average thunderstorm is surprisingly small. It is only about twenty coulombs, that is, the quantity of electricity that flows through an electric glow lamp in a minute. The thundercloud generates this quantity in five seconds, and after maintaining it at this value for some time it is forced to let it disappear as a lightning flash at a pressure of about 5,000 million volts. It is this enormous pressure that makes the discharge so spectacular and so dangerous. The thundercloud machine is continuously generating electricity at this high pressure. The author estimates that a single cloud can develop three million kilowatts of power. The motive power behind this great electrical machine is the wind, which blows up from below the cloud with tremendous force, like a gale up a chimney. It is this upward current of air which supports the cloud which may contain 300,000 tons of water, and sometimes hailstones of considerable size are suspended by it. The photographs taken of flashes in South Africa by slow-speed photography show that at first a little tongue of light stretches earthwards about 50 yards from the cloud. The light then pauses and fades out for the ten thousandth part of a second. It then reappears and stretches another 50 yards and so on until the ground is reached. Branching tongues may come from it, but the instant the leader touches the ground the main part of the stroke begins. A brilliant flame sweeps upward from the ground towards the cloud retracing the path blazed by the leader. This second stroke is much quicker, lasting only about fifty millionths of a second. The full explanation of the mechanism of this phenomenon is not yet understood. 